\title{
TINJAUAN HUKUM TERHADAP FRASA "TANPA PERSETUJUAN KORBAN" DALAM PERMENDIKBUD NOMOR 30 TAHUN 2021 TENTANG PENCEGAHAN DAN PENANGANAN KEKERASAN SEKSUAL
}

\author{
Bakhrul Amal \\ Universitas Nahdlatul Ulama Indonesia Jakarta \\ JI. Taman Amir Hamzah No.5, Pegangsaan, Kec. Menteng, Kota Jakarta Pusat, \\ Daerah Khusus Ibukota Jakarta 10320 \\ bakhrul@unusia.ac.id
}

\begin{abstract}
The problem of sexual violence in higher education is increasingly worrying. Therefore, the Ministry of Education and Culture of the Republic of Indonesia issued the Regulation of the Minister of Education and Culture Number 30 of 2021 concerning the Prevention and Handling of Sexual Violence. The regulation then sparked a polemic in the community. The problem that arises is what exactly does the phrase without the victim's consent mean?. Because it is included in the qualification of crime, the articles containing the phrase "without the victim's consent" are included in what type of article? This issue is important to be answered in order to end the pros and cons that are starting to be counterproductive in society considering that the number of victims of sexual violence is increasing. The author tries to examine this problem with a normative juridical legal research method. The approach used by the author is a case approach and a concept approach. The author considers that the inclusion of the phrase "without the victim's consent" is to protect the privacy and individual rights of the victim. Articles containing phrases "without the victim's consent" are not articles on legalizing adultery, but articles with the qualification of a complaint offense.
\end{abstract}

Keywords: Permendikbud 30 of 2021; Sexual Violence; Without the Victim's Consent; Complaint Offenses

\begin{abstract}
Abstrak
Permasalahan mengenai kekerasan seksual di lingkungan Perguruan Tinggi semakin mengkhawatirkan. Oleh sebab itu Kemendikbud menerbitkan peraturan Permendikbud Nomor 30 Tahun 2021 tentang Pencegahan dan Penanganan Kerekerasan Seksual. Aturan tersebut kemudian menuai polemik di masyarakat. Permasalahan yang muncul adalah apa sebenarnya arti dari frasa tanpa persetujuan korban itu sendiri?. Sebab masuk ke dalam kualifikasi kejahatan maka pasal-pasal yang memuat frasa "tanpa persetujuan korban" ini termasuk ke dalam jenis pasal apa?. Permasalahan ini penting untuk dijawab untuk mengakhiri pro kontra yang mulai kontraproduktif di masyarakat mengingat korban kekerasan seksual justru semakin meningkat. Penulis mencoba mengkaji permasalahan ini dengan metode penelitian hukum yuridis normatif. Adapun pendekatan yang digunakan penulis adalah pendekatan kasus dan pendekatan konsep. Penulis menilai bahwa dimasukannya frasa "tanpa persetujuan korban" adalah untuk menjaga privasi dan hak individu korban. Pasal-pasal yang memuat frasa "tanpa persetujuan korban" bukanlah pasal legalisasi zina melainkan pasal dengan kualifikasi delik aduan.
\end{abstract}

Kata Kunci: Permendikbud 30 Tahun 2021; Kekerasan Seksual; Tanpa Persetujuan Korban; Delik Aduan 


\section{A. Pendahuluan}

Kekerasan seksual di dunia pendidikan, utamanya di Perguruan Tinggi, tengah mengalami sorotan. Komisi Nasional Anti Kekerasan Terhadap Perempuan, yang bertugas memantau dan mencari fakta serta mendokumentasikan tentang segala bentuk kekerasan terhadap perempuan, mencatat bahwa dari tahun 2015 hingga Agustus 2020 setidaknya terdapat 51 aduan yang telah diterima. Adapun rinciannya adalah pada 2015 diadukan 3 kasus, tahun 2016 diadukan 10 kasus, tahun 2017 diadukan 3 kasus, tahun 2018 diadukan 10 kasus, meningkat pada tahun 2019 menjadi 15 kasus dan sampai Agustus 2020 telah diadukan 10 kasus. Dari 51 kasus tersebut diketahui bahwa Perguruan Tinggi menempati urutan pertama dengan total $27 \%$ yang kemudian diikuti oleh pesantren atau pendidikan berbasis Agama Islam sebanyak 19\%, 15\% terjadi ditingkat SMU/SMK, 7\% terjadi di tingkat SMP, dan 3\% masingmasing di TK, SD, SLB, dan Pendidikan Berbasis Kristen ${ }^{1}$.

Kementerian Pendidikan dan Kebudayaan, sebagai kementerian yang menangani persoalan pendidikan di Perguruan Tinggi, merespon kekhawatiran masyarakat terhadap kekerasan seksual di Perguruan Tinggi tersebut dengan membuat aturan. Aturan itu diterbitkan pada tahun 2021 dengan diberi nama Peraturan Mendikbud Ristek atau Permendikbud Ristek Nomor 30 Tahun 2021 tentang Pencegahan dan Penanganan Kekerasan Seksual.

Pada awal penerbitannya aturan tersebut kemudian menuai berbagai macam polemik dan penolakan. Salah satu hal krusial yang menjadi bahasan untuk dilakukan penolakan adalah munculnya frasa "tanpa persetujuan korban". Frasa "tanpa persetujuan korban" tersebut dinilai oleh beberapa pihak sebagai frasa yang mengarah pada idiologi liberal yang bertentangan dengan Pancasila. Frasa "tanpa persetujuan korban" juga dianggap sebagai upaya Pemerintah melegalisasi perzinahan ${ }^{2}$. Alasan itu muncul atas asumsi apabila kedua pihak setuju, yakni terduga pelaku dan korban, artinya perbuatan asusila itu akan dianggap benar meskipun secara moral dan nilai-nilai keagamaan jelas-jelas dianggap sebagai sebuah kesalahan.

Jika merujuk pada aturan yang dibentuk artinya Permendikbud Nomor 30 Tahun 2021 ini adalah aturan yang mengatur perihal kejahatan. Kejahatan yang dimaksud adalah kekerasan seksual. Dalam pembagian hukum artinya Permendikbud Nomor 30 Tahun 2021 ini masuk ke dalam materi persoalan pidana meskipun dalam Permendikbud Nomor 30 Tahun 2021 ini sanksi yang diatur lebih diarahkan kepada persoalan administrasi. Hal ini tidak lain dilakukan karena Pimpinan Perguruan Tinggi bukanlah penyelidik, penyidik, penuntut umum ataupun juga

1 Komisi Nasional Anti Kekerasan Terhadap Perempuan, Lembar Fakta Kekerasan Seksual Di Lingkungan Pendidikan Komisi Nasional Anti Kekerasan terhadap Perempuan, 27 Oktober 2020, hlm 1

2 Pasal 5 Ayat 2 Permendikbud Nomor 30 Tahun 2021 Jadi Sorotan, Ini Isinya, tersedia di website https://news.detik.com/berita/d-5811770/pasal-5-ayat-2-permendikbud-30-jadi-sorotan-ini-isinya. 
Majelis Hakim yang dapat mewakili negara untuk melakukan proses pemidanaan. Meskipun demikian, menurut Permendikbud Nomor 30 Tahun 2021, tidak menutup kemungkinan persoalan kekerasan seksual yang terjadi di Perguruan Tinggi nantinya akan dilanjutkan kepada mekanisme pidana (Pasal 18 Permendikbud Nomor 30 Tahun 2021).

Pada persoalan pidana dikenal istilah delik. Delik dalam KBBI diartikan sebagai perbuatan yang dapat dikenakan hukuman karena merupakan pelanggaran terhadap undang-undang; tindak pidana. Sementara di dalam teori pidana delik adalah perbuatan yang melanggar hukum yang dilakukan dengan kesalahan oleh orang yang mampu bertanggung jawab dan pelakunya diancam dengan pidana. ${ }^{3}$

Delik sendiri dibedakan menurut beberapa keadaan, salah satunya adalah adanya perbedaan delik biasa dan delik aduan. Delik aduan (klacht delict) adalah tindakan pidana yang penuntutannya hanya dilakukan atas dasar adanya pengaduan dari pihak yang berkepentingan. ${ }^{4}$ Berbeda dengan delik aduan, delik biasa (gewone delicten) lebih memprioritaskan pada kepentingan privat setiap warga negara yang disebut sebagai kepentingan umum. ${ }^{5}$ Perkara yang termasuk dalam kategori delik biasa tidak dapat dimohonkan penghentian perkaranya meskipun para pihak telah memutuskan untuk berdamai.

Penulis menilai belum ada yang melakukan penelitian terkait persoalan ini dari sudut pandang hukum secara utuh. Persoalan ini terbilang baru mengingat Permendikbud Nomor 30 Tahun 2021 sendiri diketahui diterbitkan pada Bulan November Tahun 2021. Oleh sebab itu penulis tidak menemukan penelitian sebelumnya yang dapat dikategorikan ke dalam bagian state of the art dari penulisan artikel penulis ini.

Penelitian penulis ini akan menjawab dua permasalahan. Permasalahan pertama adalah terkait "Apa yang dimaksud dengan frasa "tanpa persetujuan korban"?". Pertanyaan kedua "Termasuk di dalam delik apakah Pasal yang memuat frasa "tanpa persetujuan korban"? Penulis menilai dua permasalahan ini penting untuk dijawab agar problem perihal Permendikbud Nomor 30 Tahun 2021 yang bertujuan menciptakan rasa aman di lingkungan Perguruan Tinggi ini dapat terlaksana sesuai dengan harapan.

\footnotetext{
3 Teguh Prasetyo, Hukum Pidana, Depok, Raja Grafindo, 2014, hlm 217.

Ibid, hlm 58

5 Fitria Pratiwi Rasyid, Kajian Relevansi Delik Aduan Pada Implementasi Undang-Undang Hak Cipta, Mimbar Hukum Volume 32, Nomor 2, Juni 2020, hlm 216.
} 


\section{B. Metode Penelitian}

Penelitian ini akan menggunakan metode penelitian hukum yuridis normatif. Penelitian hukum yuridis normatif sendiri mengedepankan data sekunder 6 . Data sekunder dalam penelitian ini terdiri dari tiga bahan. Pertama bahan primer yang meliputi aturan perundangundangan dari mulai Undang-Undang Dasar NRI 1945 hingga Permendikbud Nomor 30 Tahun 2021. Kedua bahan hukum sekunder berupa jurnal dan artikel ilmiah terkait kekerasan seksual. Terakhir adalah bahan hukum tersier yaitu kamus hukum dan kamus bahasa.

Penelitian ini menggunakan pendekatan kasus dan pendekatan konseptual. Kasus yang dibahas adalah permasalahan terkait frasa "tanpa persetujuan korban". Sementara konsep yang hendak ditawarkan adalah konsep memandang persoalan secara objektif sesuai dengan kaidah hukum nasional. Data yang terkumpul akan dianilisis dengan cara interpretasi menggunakan metode gramatikal ${ }^{7}$. Dimana di dalam metode gramatikal kita dapat mengetahui maksud dan kehendak pembuat peraturan ketika hendak membuat peraturan tersebut.

\section{Hasil dan Pembahasan}

\section{Frasa "Tanpa Persetujuan Korban"}

Untuk memahami frasa "tanpa persetujuan korban" maka kita perlu memahami terkait dengan kekerasan seksual terlebih dahulu. Hal ini perlu dilakukan sebab keduanya berkaitan. Tidak akan muncul upaya melakukan konfirmasi persetujuan korban tanpa didahului adanya suatu keadaan yang memenuhi maksud kekerasan seksual.

Kekerasan seksual, atau lebih sering dikenal dengan pelecehan seksual, menurut Mc Logan adalah "form of unwanted verbal, non-verbal or physical conduct of a sexual nature occurs, with the purpose or effect of violating the dignity of a person, in particular when creating an intimidating, hostile, degrading, humiliating or offensive environment". Mc Logan memahami bahwa pelecehan seksual tidak sebatas pada perilaku seksual secara fisik tetapi juga yang bersifat verbal. Munculnya perilaku seksual tersebut tidak diinginkan oleh kedua belah pihak dan memiliki tujuan yang berakibat pada pelanggaran martabat seseorang, khususnya serta menciptakan suasana yang mengintimidasi, mengundang permusuhan, merendahkan dan mempermalukan seseorang.

6 Amiruddin \& Zainal Asikin, Pengantar Metode Penelitian Hukum, Depok, Raja Grafindo Persada, hlm 118.

7 R. Soeroso, Pengantar IImu Hukum, Depok, Sinar Grafika, 2008, hlm 100.

8 Hussin Jose Hejase, Sexual Harassment in the Workplace: An Exploratory Study from Lebanon, Journal Journal of Management Research ISSN 1941-899X 2015, Vol. 7, No. 1, hlm 108. 
Definisi lain dari kekerasan seksual bisa kita temukan dalam aturan yang diterbitkan oleh Equal Employment Opportunity Commission (EEOC). EEOC sendiri adalah lembaga yang menegakan hukum terkait persoalan diskriminasi di lingkungan kerja di Amerika Serikat. EEOC mendefinisikan kekerasan seksual sebagai “..unwelcome sexual advances, requests for sexual favors, and other verbal or physical conduct of a sexual nature constitute sexual harassment when this conduct explicitly or implicitly affects an individual's employment, unreasonably interferes with an individual's work performance, or creates an intimidating, hostile, or offensive work environment ${ }^{9}$. Hampir serupa dengan pendapat Mc Logan, EEOC juga menilai bahwa kekerasan seksual adalah rayuan seksual yang tidak diinginkan, permintaan untuk bantuan seksual, dan perilaku verbal atau fisik lainnya yang bersifat seksual merupakan pelecehan seksual ketika perilaku ini secara eksplisit atau implisit mempengaruhi pekerjaan seseorang, secara tidak wajar mengganggu kinerja seseorang, atau menciptakan intimidasi, permusuhan di lingkungan kerja.

Permendikbud Nomor 30 Tahun 2021 sendiri memaknai kekerasan seksual serupa dengan pendapat Mc Logan maupun aturan yang dibuat oleh EEOC. Merujuk pada Pasal 1 angka 1 Permendikbud Nomor 30 Tahun 2021 Kekerasan Seksual adalah setiap perbuatan merendahkan, menghina, melecehkan, dan/atau menyerang tubuh, dan/atau fungsi reproduksi seseorang, karena ketimpangan relasi kuasa dan/atau gender, yang berakibat atau dapat berakibat penderitaan psikis dan/atau fisik termasuk yang mengganggu kesehatan reproduksi seseorang dan hilang kesempatan melaksanakan pendidikan tinggi dengan aman dan optimal. Arti dari kekerasan seksual dalam pemahaman Permendikbud Nomor 30 Tahun 2021 tentunya, jika meninjau dari pemahaman umum, telah memenuhi standard dan tidak terlalu out of context yang berpotensi terhadap kesewenang-wenangan di dalam penerapan aturan hukum.

Perbedaan definisi kekerasan seksual antara Permendikbud Nomor 30 Tahun 2021 dan definisi Mc Logan serta EEOC terdapat pada penekanan terkait frasa "tidak diinginkan". Baik Mc Logan maupun EEOC keduanya memasukan kata "tidak diinginkan" dalam hal mendefinisikan perihal kekerasan seksual. Mc Logan menggunakan frasa "unwanted" sementara EEOC menggunakan "unwelcome".

Berbeda dengan Mc Logan dan EEOC, Permendikbud 30 Tahun 2021 menggunakan frasa berbeda untuk hal-hal yang perlu dikonfirmasi terlebih dahulu kepada Korban. Frasa "tidak diinginkan" yang lebih lazim digunakan dalam persoalan kekerasan seksual melalui Permendikbud 30 Tahun 2021 lebih dimaknai dengan frasa "tanpa persetujuan korban". Di dalam Permendikbud 30 Tahun 2021 sendiri tidak semua tindakan harus dengan persetujuan

9 James Quick dan Ann McFayden, Sexual Harassment: Have We Made Any Progress?, Journal of Occupational Health Psychology 2017, Vol. 22, No. 3, hlm 288 
korban. Berdasarkan analisis penulis terdapat 6 jenis tindakan yang memerlukan persetujuan korban antara lain :

1. Memperlihatkan alat kelaminnya dengan sengaja tanpa persetujuan Korban (Pasal 5 ayat (2) huruf b);

2. Mengambil, merekam, dan/atau mengedarkan foto dan/atau rekaman audio dan/atau visual Korban yang bernuansa seksual tanpa persetujuan Korban (Pasal 5 ayat (2) huruf f);

3. Mengunggah foto tubuh dan/atau informasi pribadi Korban yang bernuansa seksual tanpa persetujuan Korban (Pasal 5 ayat (2) huruf g);

4. Menyebarkan informasi terkait tubuh dan/atau pribadi Korban yang bernuansa seksual tanpa persetujuan Korban (Pasal 5 ayat (2) huruf h);

5. Menyentuh, mengusap, meraba, memegang,memeluk, mencium dan/atau menggosokkan bagian tubuhnya pada tubuh Korban tanpa persetujuan Korban (Pasal 5 ayat (2) huruf I);

6. Membuka pakaian Korban tanpa persetujuan Korban (Pasal 5 ayat (2) huruf $\mathrm{m}$ );

Baik menggunakan frasa unwanted, unwelcome, maupun "tanpa persetujuan korban" penulis menilai tujuannya tetap sama. Tujuannya adalah tentu untuk memperjelas bahwa bentuk-bentuk kekerasan seksual dimaksud hanya bisa memenuhi syarat ditindaklanjuti sebagai kekerasan seksual apabila korban atau pihak yang dirugikan tidak menginginkan atau tidak setuju. Hal demikian penting untuk menghargai privasi setiap orang dan menghargai hakhak individu yang dianggap sebagai korban oleh pihak-pihak di luar komunikasi kedua belah pihak terkait.

\section{Rumusan Delik Dalam Frasa "Tanpa Persetujuan Korban"}

Delik, menurut Simons, merupakan tindakan melanggar hukum yang telah dilakukan dengan sengaja ataupun tidak dengan sengaja oleh seseorang yang seseorang itu dapat bertanggung jawab atas tindakannya dan yang oleh undang-undang telah dinyatakan sebagai suatu tindakan yang dapat dihukum ${ }^{10}$. Delik sendiri merupakan padanan kata yang sama dengan strafbaar feit. Strafbaar feit terdiri dari tiga kata, yakni straf, baar, dan feit, dimana kata "straf" artinya pidana, "baar" artinya dapat atau boleh dan "feit" adalah perbuatan sehingga strafbaar feit secara keseluruhan adalah suatu perbuatan yang dapat dipidana ${ }^{11}$.

10 Sudaryono dan Natangsa Surbakti, 2005, Buku Pegangan Kuliah Hukum Pidana, Surakarta: Muhammadiyah University Press, hIm 115.

11 Adami Chazawi, Pelajaran Hukum Pidana Bagian I, Jakarta: Rajawali Pers, 2011, hlm.69. 
Delik sendiri banyak jenis dan macamnya seperti delik umum, delik khusus, delik aduan, delik kealpaan dan delik lainnya termasuk juga terkait dengan diprosesnya suatu tindak pidana dilihat menurut karakteristik delik aduan dan delik biasa.

Delik aduan merupakan delik tindak pidana yang syarat penuntutannya hanya dapat dilakukan apabila ada pengaduan dari orang yang dirugikan. Sedangkan delik biasa adalah tindak pidana yang dapat dituntut tanpa diperlukan adanya suatu pengaduan bahkan apabila kedua pihak telah melakukan perdamaian ${ }^{12}$.

Di dalam KUHP memang tidak dijelaskan tentang delik aduan secara khusus dan eksplisit. Delik aduan sendiri, meskipun tidak terdefinisikan secara jelas, dapat dipahami dan diperhatikan pada frasa "adanya pengaduan" pada pasal-pasal tertentu seperti di dalam persoalan pidana perzinahan. Pasal 284 ayat (2) KUHP, terkait perzinahan, menyebutkan "penuntutan hanya dilakukan atas pengaduan suami atau isteri yang mendapat malu.....". Maksud daripada pengaduan itu sendiri bisa kita temukan dalam Pasal 1 butir 25 KUHAP yang berarti pemberitahuan disertai permintaan oleh pihak yang berkepentingan kepada pejabat yang berwenang untuk menindak menurut hukum seorang yang telah melakukan tindak pidana aduan yang merugikannya.

Penjelasan di atas memberikan beberapa pemahaman antara lain : 1) Kejadian tindak pidananya harus diberitahu terlebih dahulu; 2) Pemberitahuan itu disertai permintaan oleh pihak yang berkepentingan; dan 3) Permintaan itu diajukan kepada pejabat yang berwenang untuk menindak menurut hukum seorang yang telah melakukan tindak pidana aduan yang merugikannya.

Dalam persoalan delik aduan, untuk dapat ditindaklanjuti perkaranya bukan hanya pihak yang berkepentingan itu memberitahukan akan tetapi juga pemberitahuan itu mastilah disertai permintaan. Pemberitahuan ini tidak dilakukan oleh sembarangan orang melainkan hanya dilakukan oleh pihak yang berkepentingan. Pemberitahuan dimaksud juga hanya disampaikan kepada pejabat yang berwenang. Tidak dapat dibenarkan atau diproses apabila aduan itu dilakukan bukan kepada pejabat yang tidak berwenang ${ }^{13}$.

Menurut pasal a quo jika tidak ditemukan adanya aduan, meskipun bagi sebagian pihak mungkin dianggap sebagai perbuatan pidana, persoalan pidana tersebut tidak dapat ditindak lanjuti. Adanya delik aduan dalam KUHP, menurut ilmu pengetahuan hukum pidana, adalah karena kepentingan pribadi dari yang terkena kejahatan lebih diutamakan dan dipentingkan dari pada kepentingan hukum masyarakat. Oleh sebab itu maka penuntutannya digantungkan pada

12 P.A.F. Lamintang, Dasar-Dasar Hukum Pidana Indonesia, Bandung : Citra Aditya Bakti, 1997, hlm 217-218

13 Wempi Jh. Kumendong, Kemungkinan Penyidikan Delik Aduan Tanpa Pengaduan, Jurnal Hukum Unsrat Vol. 23/No. 9/April/2017, hlm 60. 
kehendak dari yang berkepentingan. Tujuannya adalah agar jangan sampai penuntutan terhadap pelaku justru akan lebih merugikan lagi pihak yang berkepentingan ${ }^{14}$. Ringkasnya, menurut G. Bawengan, delik aduan merupakan penghormatan terhadap hak asasi manusia, karena adanya pemberian kesempatan kepada seseorang yang berhak mengadu dalam hal delik-delik tertentu untuk dituntut atau tidak dituntut oleh jaksa penuntut umum ${ }^{15}$.

Delik yang memuat frasa "tanpa persetujuan korban" dalam Permendikbud Nomor 30 Tahun 2021 jika kita korelasikan dengan pemahaman delik di atas artinya termasuk ke dalam delik aduan. Frasa "tanpa persetujuan korban" secara jelas dan terang artinya mewajibkan konfirmasi, atau dalam bahasa pidana adanya pengaduan, dari pihak yang diduga dirugikan bahwa dia adalah korban kekerasan seksual. Maksudnya adalah kekerasan seksual tersebut (5 jenis kekerasan seksual dengan frasa "tanpa persetujuan korban") hanya bisa ditindaklanjuti apabila Tim Satuan Tugas Pencegahan dan Penanganan Kekerasan Seksual menerima pengaduan langsung dari korban bukan dari pihak lain yang tidak berkepentingan. Dengan kata lain Tim Satuan Tugas Pencegahan dan Penanganan Kekerasan Seksual hanya bisa melihat bahwa telah timbulnya permasalahan apabila korban merasa tidak setujui.

Terkait adanya asumsi bahwa frasa "tanpa persetujuan korban" dalam Permendibud 30 Tahun 2021 merupakan upaya legalisasi perzinahan penulis menilai hal tersebut adalah asumsi yang out of the blue. Asumsi tak berdasar yang jauh dari konteks perdebatan perihal ilmu hukum baik secara samar-samar maupun terang benderang. Aturan mengenai perzinahan dalam hukum Indonesia telah banyak di atur di dalam ketentuan lain semisal aturan larangan melakukan tindak pidana perzinahan, tindak pidana pelecehan seksual, aturan perlindungan anak, pelarangan prostitusi, maupun human trafficking.

\section{Simpulan}

Frasa "tanpa persetujuan korban" di dalam Permendikbud 30 Tahun 2021 tidak lain demi menjaga privasi dan hak individu korban. Privasi dan hak individu tersebut tidak dapat diukur dampaknya dari pihak lain di luar korban. Frasa "tanpa persetujuan korban" di dalam Permendikbud 30 Tahun 2021 juga adalah upaya untuk membedakan hal-hal mana saja yang dapat ditindak lanjuti oleh Tim Satuan Tugas Pencegahan dan Penanganan Kekerasan Seksual secara langsung maupun tidak. Pada ilmu pidana hal ini sering dikenal dengan pemisahan antara delik aduan dan delik biasa.

Pemerintah, dalam hal ini Kementerian Pendidikan dan Kebudayaan, perlu melakukan perubahan di dalam politik komunikasinya utamanya terkait dengan kebijakan. Apapun

14 Ibid, hlm 60

15 Gerson W. Bawengan, Kriminologi, Jakarta : Bina Aksara Jakarta, 2003, hlm 172 
bentuknya kebijakan adalah suatu produk hukum. Oleh sebab itu Kementerian Pendidikan dan Kebudayaan perlu melibatkan para ahli-ahli di bidang hukum dalam menawarkan atau mempertahankan argumentasinya kepada masyarakat. Selanjutnya Kementerian Pendidikan dan Kebudayaan harus mampu menghindari bahasa-bahasa yang multitafsir dan mengharmonisasi norma-norma di dalam kebijakannya sesuai dengan asas hukum yang berlaku agar kebijakan yang dikeluarkan tersebut tidak menimbulkan polemik.

\section{DAFTAR PUSTAKA}

\section{Buku:}

Adami Chazawi, Pelajaran Hukum Pidana Bagian I, Jakarta: Rajawali Pers, 2011

Amiruddin \& Zainal Asikin, Pengantar Metode Penelitian Hukum, Depok, Raja Grafindo Persada

Gerson W. Bawengan, Kriminologi, Jakarta : Bina Aksara Jakarta, 2003

P.A.F. Lamintang, Dasar-Dasar Hukum Pidana Indonesia, Bandung : Citra Aditya Bakti, 1997

R. Soeroso, Pengantar IImu Hukum, Depok, Sinar Grafika, 2008

Sudaryono dan Natangsa Surbakti, 2005, Buku Pegangan Kuliah Hukum Pidana, Surakarta: Muhammadiyah University Press

Teguh Prasetyo, Hukum Pidana, Depok, Raja Grafindo, 2014

\section{Jurnal:}

Fitria Pratiwi Rasyid, Kajian Relevansi Delik Aduan Pada Implementasi Undang-Undang Hak Cipta, Mimbar Hukum Volume 32, Nomor 2, Juni 2020

Hussin Jose Hejase, Sexual Harassment in the Workplace: An Exploratory Study from Lebanon, Journal Journal of Management Research ISSN 1941-899X 2015, Vol. 7, No. 1

James Quick dan Ann McFayden, Sexual Harassment: Have We Made Any Progress?, Journal of Occupational Health Psychology 2017, Vol. 22, No. 3

Komisi Nasional Anti Kekerasan Terhadap Perempuan, Lembar Fakta Kekerasan Seksual Di Lingkungan Pendidikan Komisi Nasional Anti Kekerasan terhadap Perempuan, 27 Oktober 2020

Wempi Jh. Kumendong, Kemungkinan Penyidikan Delik Aduan Tanpa Pengaduan, Jurnal Hukum Unsrat Vol. 23/No. 9/April/2017 
Tinjauan Hukum terhadap Frasa "Tanpa Persetujuan Korban" dalam Permendikbud Nomor 30 Tahun 2021

Tentang Pencegahan dan Penanganan Kekerasan Seksual

\section{Internet:}

Pasal 5 Ayat 2 Permendikbud Nomor 30 Tahun 2021 Jadi Sorotan, Ini Isinya, tersedia di website https://news.detik.com/berita/d-5811770/pasal-5-ayat-2-permendikbud-30-jadisorotan-ini-isinya. 